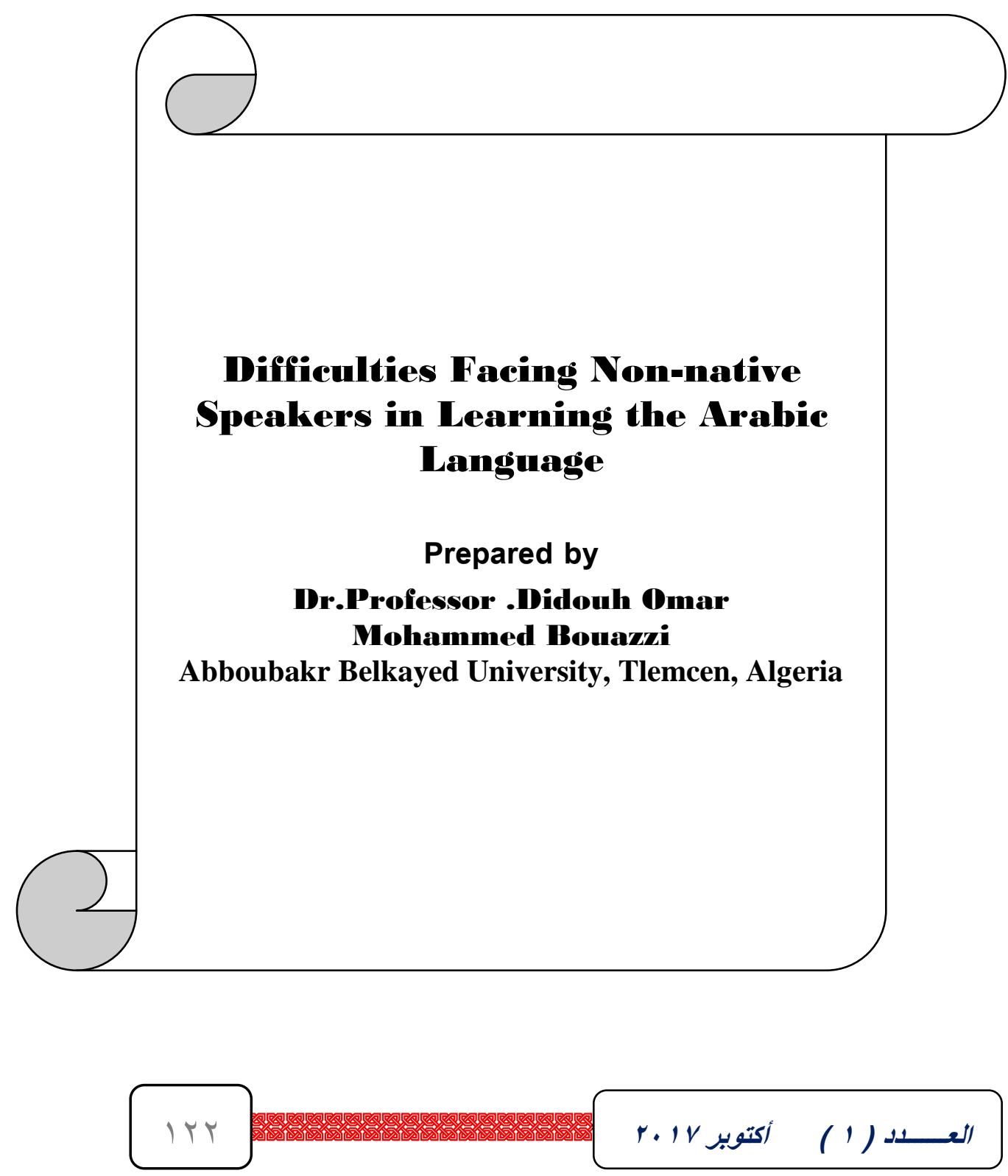




\section{Difficulties Facing Non-mative Speakers in Learning the Arabic Language}

Prepared by

\section{Dr.Professor .IDidouh Drmar}

Mohammed Bouazxi

Abboubakr Belkayed University, Tlemcen, Algeria

الملخص:

نستعرض في هذا البحث ملامسة أوجه الخلل في تشخيص صعوبة نطق

بعض الأصوات العربية لاى المتعلمين لها من غير أهلها، مما يسبب عائقا في تعلم

اللغة العربية كلية. ومن هنا يأتي البحث ليسد ثغرة لا يمكن تجاوزها في تعليمية العربية

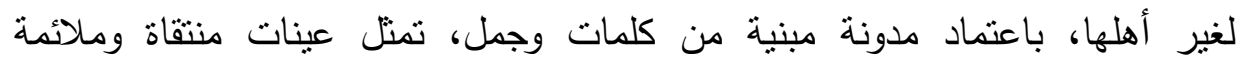
للاختبار والقياس.

\section{Abstract:}

the review in this search touching the imbalances in the diagnosis of the difficult pronunciation of some Arabic voices to educated people from non-residents, causing an obstacle to learn Arabic language.in all. From herethere research comes filled a gap that could not be overcome in the Arabic educational Nonspeaking people, and the adoption of a corpora built from the words and sentences, selective samples and convenient for test and measurement.

Keywords: difficulties in learning a foreign language-nature of languages- interference of languages-approaches- solutions

\section{Introduction:}

In this research, we try to tackle to the main obstacles that face

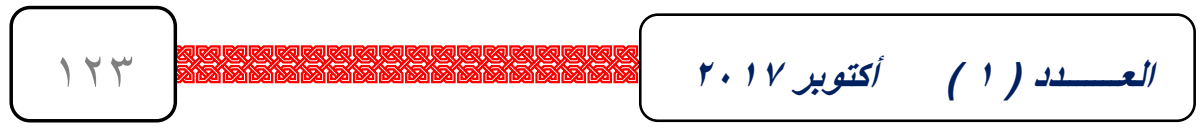




\section{المبلة العربية الاناطقين بغيرها}

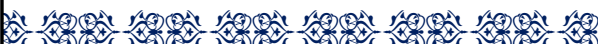

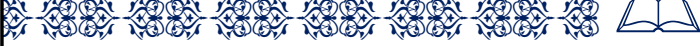

non-native speakers in studying Arabic language. These problems emerge in different aspects depending on the age and the environment of the learner. However,some are due to the nature of the language in terms of similarities and differences. These two factors are among the aspects of difficulty or easiness.

The learner who studies a foreign language makes many errors unconsciously, due to the interference of languages or the transfer of his linguistic habits, his knowledge, and his language syntax ${ }^{1}$ whether in connection with sounds or words and sentences from the mother tongue to the target language. So problems related to morphology and constructions of sentences arise, such as omitting elements from a sentence or choosing another false element.

In this research, we try to find scientific explanations to these obstacles that can be caused either by slips of the tongue as supplementation, repetitions or copying or to the factors of learning and lack of knowledge. We have also supplied appropriate solutions to remedy and enable both the teacher and the learner to get better results.

\section{Linguists' Contemporary Views in Learning Languages:}

Walid Annati sees that teaching a language is an important field of Applied Linguistics ${ }^{2}$.The method a learner acquires a second language is what mostly interests scientists and researchers.

In the last century, linguists started searching in different issues related to the learning and teaching process of a second language ${ }^{3}$, especially in the absence of Applied Education within Applied Linguistics. That caused a deception and disappointment for inspectors and teachers. They lacked such studies that would help them overcome difficulties in their work. ${ }^{4}$

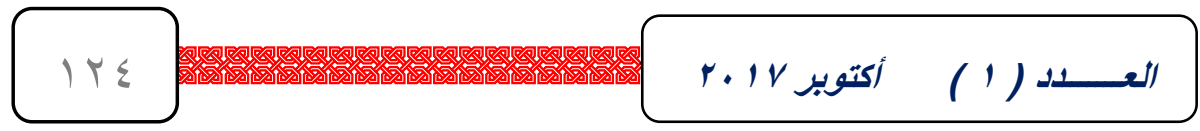




\section{الهبلة العربية اللناطقين بغيرها}

为,

今

What is important in this research is to exploit the results in the learning process which will be beneficial at the practical level in the class. ${ }^{5}$ What and how do we study? These two questions are related to each other. The first question is related to the subject from its quality and quantity. The latter is linked to the kinds of learners, their needs and interests. Then the transformation of these needs and interests into concepts. ${ }^{6}$

"What do we study?" is the subject and knowledge taught or inculcated to a group of learners."How do we study?" is the pedagogical methods used in language learning throughout time like the Grammar Translation Method or the Direct Method which came as an answer to the Grammar Translation Method. Then appeared the Audio-lingual Method which spread considerably after the Second World War. Later, the Structural Method emerged in England in the mid-fifties.

\section{Theories' Claims Related To Learning Foreign Languages:}

In Walid Annati's book "Applied Linguistics and TeachingArabic to Non-native Speakers" different schools strongly related to Educational Psychology have emerged. The most important ones are:

1- The Behavioural Theory

2- The Cognitive Theory

3- The Data Processing Method ${ }^{7}$

He thus emphasizes on the three theories. The first one links between environmental events and behaviour as it is based on (stimulus and response). The second theory gives priority to internal processes related to thinking and problem solving $\mathbf{8}^{\text {. }}$ However, the third one deals mainly with the ways information is stored in memory and recalledwhen needed.

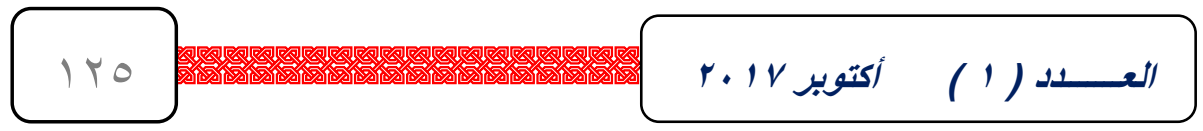




\section{العبلة العربية اللناطقين بغيرها.}

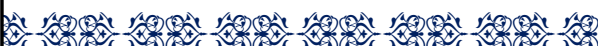

今

Some may wonder if learning a mother language is identical to that of a target language. Of course there is a similarity to some extent either according to theBehavioural Theory advocated by Skinner or the Cognitive one advocated by Chomsky. Hence, we have to mention that learning a second language ${ }^{\text {' }}$ is a very complex process due to cognitive and psychologicalfactors ${ }^{\mathbf{1 0}}$.

\section{Psychology and the Process of Language Learning:}

Different theories tackled the psychological aspect in acquiring foreign languages. In spite of their divergence, they have greatly benefited researchers in pedagogy. They have also paved the way for them to elaborate learning methods and making better for a learner to acquire his language. ${ }^{11}$

\section{Agreement Factor:}

It is among the theories which focused on acquiring L1 and L2 languages.Such theories that claim congruency between the acquisition of a mother tongue and the learning of a target language ignored the factors mentioned previously. Those factors influence negatively the process of learning both languages. On the other hand, they (theories) focused on the similarity of strategies used in learning a mother language and a foreign one. ${ }^{\mathbf{1 2}}$

\section{Differentiation Factor:}

It is also called Contrastive Analysis Approach which is based on the hypothesis that "the learner's native language constitutes a strong element in learning a second language, and thus it cannot be ignored or excluded from the learning process."13 The same is seen by El Rajihi in his book "Applied Arabic Language and Education" when talking about the factors affecting the learning of L2, mainly the similarities and differences of the learner's native language and the target language. If the learner discovers that he

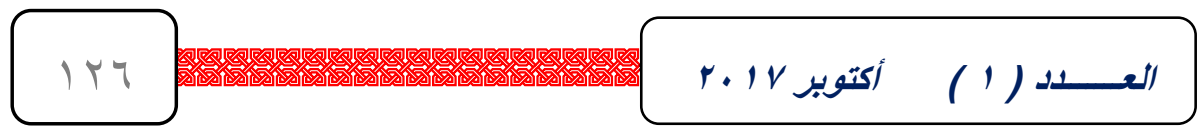


knows something of L2 similar his mother language, learning will be easier for him.

But if he finds L2 completely different from his native language, learning will be difficult for him. ${ }^{\mathbf{1 4}}$

\section{Accuracy Factor:}

Learning takes place in two ways:

\section{Unconsciously:}

It is the use of language for communication purposes related to life. It doesn't matter if the learner doesn't master the foreign language's rules. His main concern is only to communicate with other people when exposedto real situations through "exchanging knowledge and experiences". ${ }^{15}$ The nature of the contact as seen by Ahmed RochediToeima"is determined by what these situations impose of linguistic and cultural requirements."16 A L2 learner can then communicate better. For instance, when looking for a house to rent, he is required to sign a contract and ask about the lease and the residency condition and its situation. ${ }^{17}$

\section{Consciously:}

It is completely different from the first factor, as the learner seeks to master the structures and rules of the language ${ }^{\mathbf{1 8}}$, by attending regular tutorial classes.

\section{Approaches Tackling the Obstacles of Learning Languages The Analysis Approach:}

In his book "In the Science of Contrastive Languages", DadraouiZahran shows the importance of contrastive studies to identify

difficulties, and help the teacher prepare remedial work and practice models to deal with the learner's shortcomings so that obstacles and problems impeding progress in acquiring a second language could be reduced or solved. ${ }^{19}$

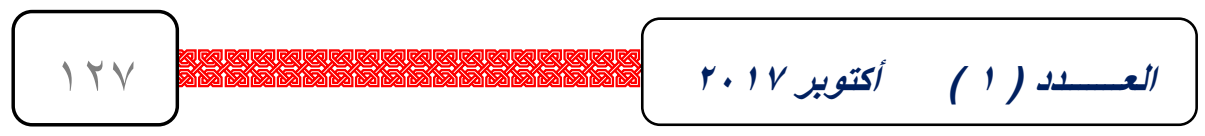




\section{المبلة العربية للناطقين بغيرها}

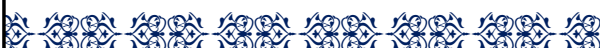
今

Despite all criticism concerning the efficiency of this approach, it has proved its pedagogical value in helping teachers provide linguistic materials and devise appropriate methods to teach languages. "It is an approach based on contrasting two levels in language use and thus, it can provide good help to learners." 20

RochediToeimaconsiders it "as a tool to predict obstacles that native speakers can face when dealing with the language like pronunciation syntax, tructure,grammar,conjugation". ${ }^{21}$ Mohammed Mohamed Dawood predicted in Writing Arabic andModern Linguistics" a great future for this approach to overcome the difficulties in learning languages..."22 It contributes remarkably to the enhancement of subjects related to teaching foreign languages.

\section{TheError AnalysisApproach:}

It is an approach which emerged as a reaction to the previous one. It was considered by its advocates as a real alternative to detect the difficulty or easiness of problems. It was the unique way to know the truth about the problems faced by learners "by monitoring their linguistic errors as well as their repetition frequency rates. ${ }^{, 23}$ Not standing against any approach, the moderate position of Mahmoud Ismail ElSini and Ishaq Mohammed Amin doesn't focus on the combination of the two approaches nor is it against, so that learners can overcome and compensate the shortcomings of either approaches and also to take full advantage of the qualities of both.

and exploit all in monitoring the linguistic problems encountered by learners; ${ }^{24}$ a fact that still weighs heavily on the minds of teachers in spite of the development in the teaching methods of Arabic to non-native speakers in many Arab countries.

\section{Tests and Exams Method}

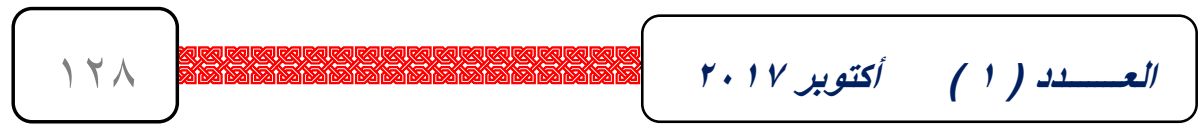




\section{الهبلة العربية اللناطقين بغيرها:}

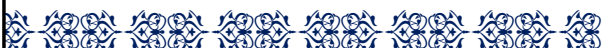
今

It is a way to discover the difficulties of the language as in listening, reading and writing. Sometimes, exams can lead to success or failure. It depends on the specificities of the exams. They can measure the learner's knowledge spontaneously but not his capacities to produce. ${ }^{25}$

\section{Factors Linked to the Difficulty of the Learning Process}

Before mentioning the main factors that can cause difficulties for non-native learners of Arabic, we have to consider the nature of the language they acquire. Generally, they acquire it from their mother language by using strategies like copying, changing, omitting, overgeneralizing. We can link these factors to two main causes:

\section{1- Language Causes}

These difficulties can be caused by the nature of the Arabic rules, and related directly to the bilingual interference.

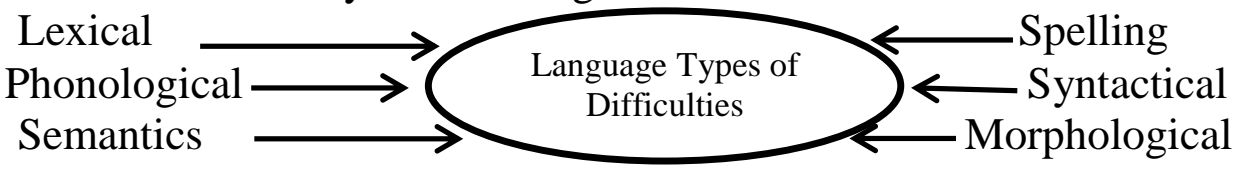

Table 01: Types of Language Difficulties

\section{a- Spelling Difficulties}

These difficulties are related basically to "incorrectand inaccurate"26 written Arabic. A non-native learner finds real difficulties in using letters and cannot distinguish between similar ones. ${ }^{27} \mathrm{He} /$ She can make the following mistakes:

- Shortened or lengthened vowels.

- Deleting letters (delete ELMADD in Alif or Yaa or Waw.

E.g. 'Manal' sis instead of 'manaal' منسال' or added (MaddofAlif or Yaa or Waw) E.g. 'Saaeed' ســاعيد' instead of " سعيد'saeed

- deletion or addition or mixing between letters and ignoring cases of writing the "hamzah'(position)

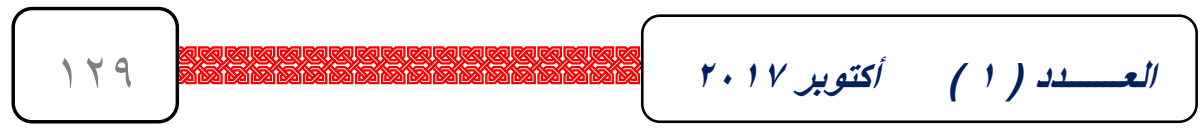




\section{الهمابة العربية الاناطقين بغيرها}

- negligence of punctuation (full stop, commas, semi-colon etc... $)^{28}$

\section{b- Phonological Difficulties}

Difficulties can vary depending on the learner's language and gender. Here are examples: Replacing the sound (fa) with the sound (p) and this is due to the absence of this sound in the learner's language. Changes can occur in the following sounds:

\begin{tabular}{|l|l|}
\hline Original sounds & Exchanged sounds \\
\hline$/ /(\mathrm{dh})$ & $/ \mathrm{j} /(\mathrm{z})$ \\
\hline$/ /(\mathrm{d})$ & $/ /(\mathrm{t})$ \\
\hline$/ \mathrm{\Delta} /(\mathrm{th} / \mathrm{t})$ & $/ \mathrm{\omega} /(\mathrm{s})$ \\
\hline$/ /(\mathrm{s})$ & $/(\mathrm{sh})$ or/ص/(ṣ) \\
\hline
\end{tabular}

Table 2: Mispronounced sounds ${ }^{29}$

In Yoruba language, they exchange the following sounds:

/ thaa- $\dot{*}(\mathrm{t}) /$ - / thel-j(dh) / - /zey-j(z)- / sin - w(s) /-

/sad - ص(ș)/ - / chin - (sh)/thaadظ(d,) / -they say :

\begin{tabular}{|c|c|c|c|}
\hline 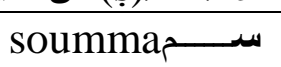 & instead of & thoumma & ثــم \\
\hline ســـالكSaalika & instead of & dhaalika & ذللك \\
\hline 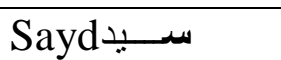 & instead of & Zayd & زيد \\
\hline سدـالمsâalim & instead of & $\underline{\mathrm{d}}$,aalim & ظالم \\
\hline
\end{tabular}

Table 2: Mischanged sounds in Yoruba Language ${ }^{\mathbf{3 0}}$

Learners of the Arabic language of other nationalities like Persian, Turkish, Urdu, Boutchou exchange /thad/ to / zey/ and $/ \mathrm{ka} /$ to /gha/. They make the sound of the two letters heavy. ${ }^{\mathbf{3 1}}$ The Malaoui student also finds difficulties in pronouncing the following sounds:

ā, zā', 'ayn , ḥā', shīn , qāf, sād ,sīn , thā',32

\section{c- Morphological Difficulties}

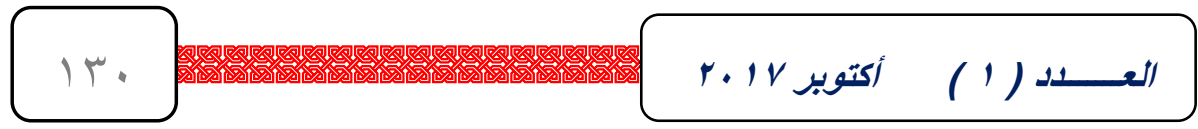


Learners use light consonants instead of heavy ones. The following table illustrates some of them:

\begin{tabular}{|c|c|}
\hline Heavy sounds & Light sounds \\
\hline$/$ ta /(b) & /t/(ت)as tabloun instead of tabloun \\
\hline / da / (ض ) & / dā/(د) as daraba instead of ḍāraba \\
\hline / șā /ص) & /s / (س) as saghiroun instead of șaghiroun \\
\hline 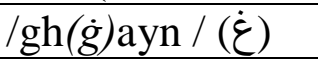 & /khā'/h,/ ( $\dot{c}$ )kho'raabou instead of ghoraabou \\
\hline / hạà'/(z) & / hā'/(॰)as mihrab instead of miḥrab \\
\hline
\end{tabular}

Table 4: Light sounds used instead of heavy ones by Americans ${ }^{33}$

They also find difficulty in distinguishing between long and short sounds and they mix them in a very apparent way as in the following cases:

- The mixture between sounds that have the same number of ابناء,Will be abna

\begin{tabular}{|c|c|c|}
\hline 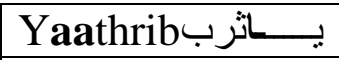 & instead of & يثرب Yathrib \\
\hline صاحــبـبـ Saahiib & instead of & صاحب sahib \\
\hline undouk فندوق & instead of & foundok فندق \\
\hline
\end{tabular}

Table 5: Mixture between short and long sounds ${ }^{\mathbf{3 4}}$

- The misplacement of letters

\begin{tabular}{|l|l|ll|}
\hline aklaba اقبل اصبل اصب & instead of & akbala \\
\hline ashaba & instead of & asbaha \\
\hline
\end{tabular}

Table 6: Misplacement of letters ${ }^{35}$

\section{d- Syntactical Difficulties}

The purpose of written exams for non-native learners of Arabic is to recognize syntactic errors. Most errors concern definite and indefinite articles, ordering, agreement and contrastivity. ${ }^{\mathbf{3 6}}$ Agreementerrors Examples (contrast instead of congruency)

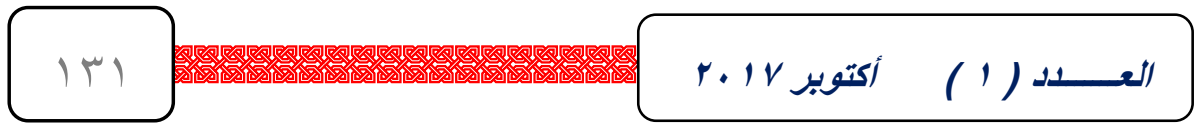




\begin{tabular}{|c|c|}
\hline $\begin{array}{l}\text { Noun followed by } \\
\text { an adjective }\end{array}$ & 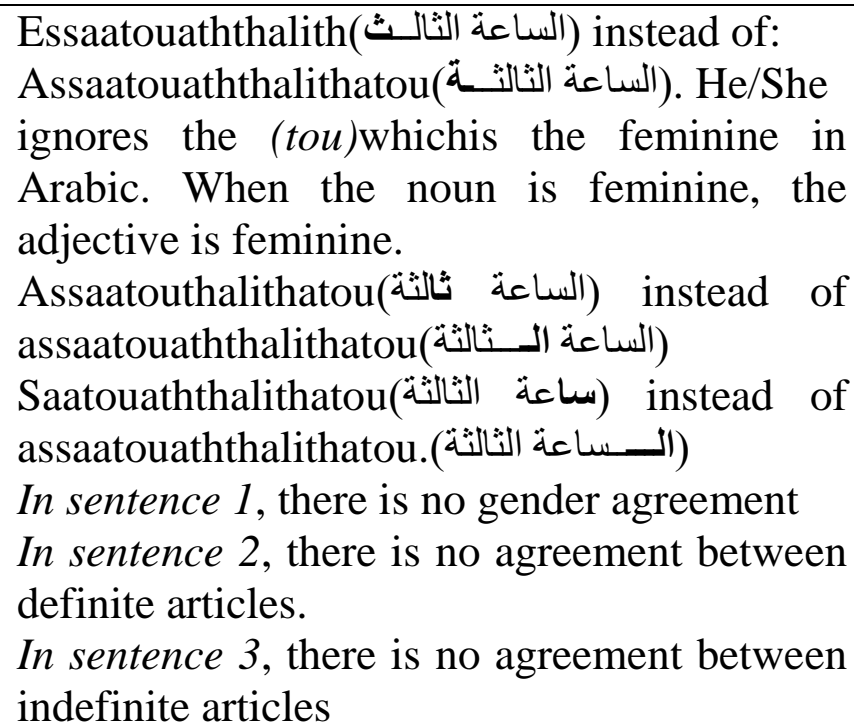 \\
\hline
\end{tabular}

\begin{tabular}{|c|c|}
\hline $\begin{array}{l}\text { Word order } \\
\text { errors }\end{array}$ & Examples \\
\hline $\begin{array}{l}\text { Shifting the } \\
\text { genitive }\end{array}$ & Dar al bab داب الدار instead ofbabaddar باب \\
\hline $\begin{array}{l}\text { Starting with the } \\
\text { object instead of } \\
\text { the subject }\end{array}$ & 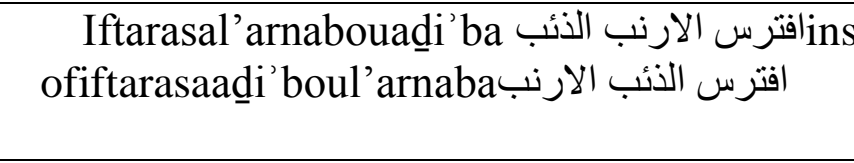 \\
\hline $\begin{array}{l}\text { Starting with the } \\
\text { predicate instead } \\
\text { of the subject }\end{array}$ & $\begin{array}{c}\text { MojtahidounAhmedoun مجتهُ احمد instead of } \\
\text { Aḥmedounmojtahidou احمد مجتهُ }\end{array}$ \\
\hline
\end{tabular}

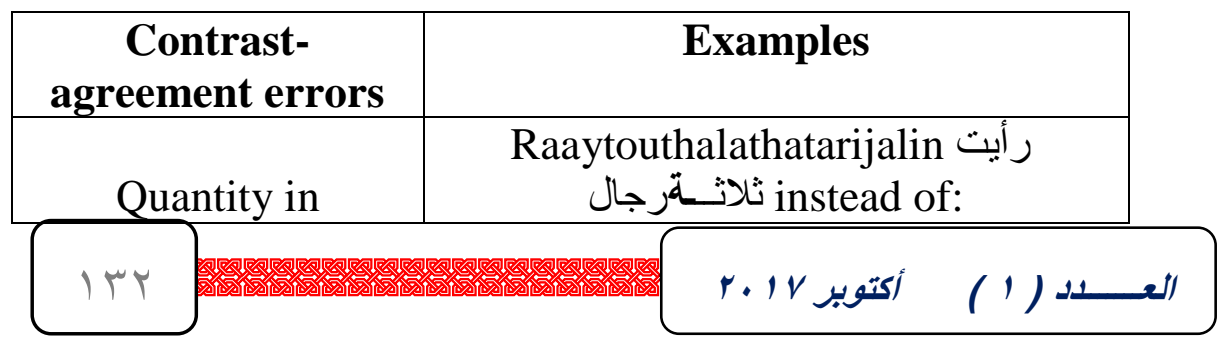




\section{الهمبة العربية للناطقين بغيرها}

我

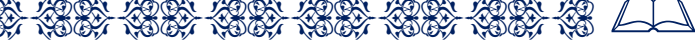

countable nouns

\section{Raaytouthalathrijal. أيت ثلا ث رجال}

The number contrasts the countable noun in single form. That means that feminine nouns take a male number. On the other hand, a masculine noun takes a female number.

Table 7: ordering, agreement, contrastivity errors ${ }^{37}$

\section{e- Lexical Difficulties}

When explaining a word by another one which is ambiguous as (alajradou=al afjajou) or by some other explanations can but strain the learner especially when he is forced to go back to the start to understand. He will spend considerable time to reach a result.

In Arabic, there is more than one synonym or explanation for one single lexical item which can create a problem for learners of Arabic even if they have a good level. ${ }^{38}$

\section{f.SemanticalDifficulties}

Foreigners learning Arabic can come across words similar in meaning but different in the form and vice versa.

\begin{tabular}{|c|c|}
\hline \multicolumn{2}{|c|}{ Similarities in form and meaning } \\
\hline Arabic & English \\
\hline / k u r’ān / & Quran/' kp ra: n/ \\
\hline جمل/dzemel/ & camel/kæm ə 1 / \\
\hline (حناء/hi n a ? / & henna/' h e n ə/ \\
\hline (عرب / Sarab / & Arab/'ærə b/ \\
\hline
\end{tabular}

Table 8: Words similar in form and meaning ${ }^{39}$






\section{المهلة العربية للناطقين بغيرها}

فيل/f i: 1/(elephant)



r

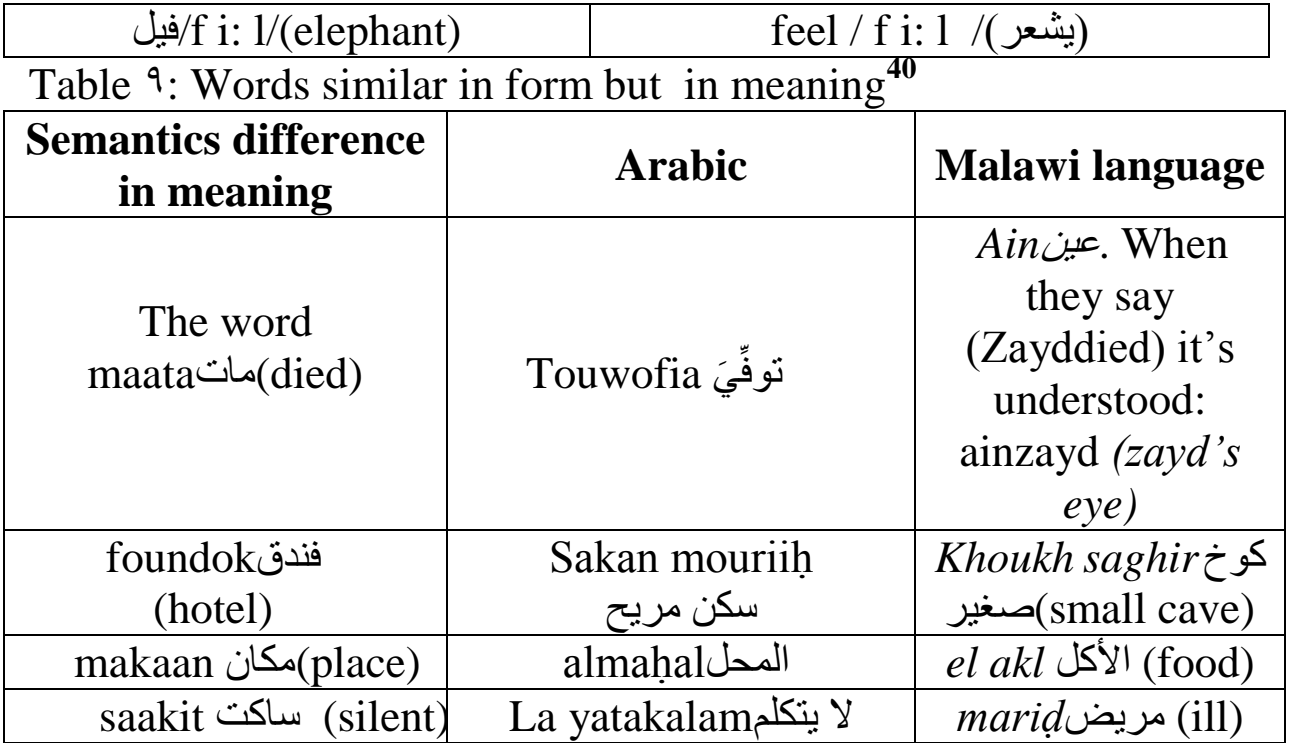

Table 10: Examples of similarities in form and differences in meaning between Arabic and Malawi ${ }^{41}$

\section{2- Non-linguistic Causes}

The curriculum for non-native learners of Arabic is different of that for native ones. Characteristics such as the learner's age, language and motivation ${ }^{42}$ are being taken into consideration by researchers so that they can devise curriculums that fit these kinds of learners. Therefore, any ignorance of L1 and L2 interference can but only make the learning process more difficult and complex. ${ }^{\mathbf{4 3}}$

\section{a- The Teacher's Characteristics}

"The teacher is the corner stone of the learning process." ${ }^{, 44} \mathrm{He}$ should use all his know-all to facilitate the learning process and help non-native Arabic speakers acquire new language skills by using creative methods in teaching.

\section{b- The Cognitive Content}

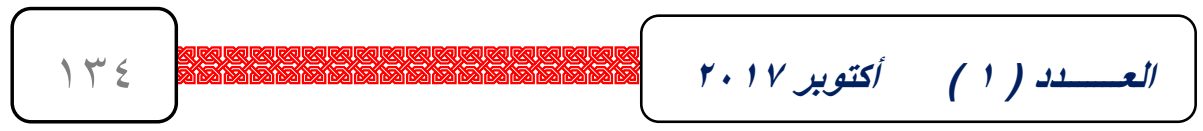




\section{العجلة العربية للناطقين بغيرها}

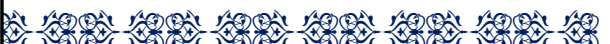

Pror

Unless it takes into consideration the learner's objectives such as learning medicine or engineering or just for social purposes (communication) and without focusing only on the official syllabus, it will be fruitless and doomed to failure. ${ }^{45}$

\section{Communication Approach to Deal with phonological difficulties:}

As we know there are various difficulties due to many causes. We can overcome these difficulties through the teacher's competence and experience. The most common errors non-native speakers of Arabic make are phonological ones. So, we have to build pedagogical strategies to non-native teachers of Arabic and give them ways to remedy in such a situation.

We have linked these strategies to the Communicative Approach that is based on practice and remedial work. Such process doesn't exist in other languages'curricula. Applying this approach can but attract more non-native speakers of Arabic get more interest and readiness to learn Arabic.

\section{Suggestions and Recommendations}

In the end, we can say that a great concern is given to the Communicative Approach in teaching Arabic to non-native speakers. To sum up, here are some suggestions and recommendations concerning the errors made in phonology by L2 learners.

- The CommunicativeApproach aims at dealing with all language skills and in real situations.

- Learners can overcome phonological problems through regular practice of pronunciation like twisting the tongue continuously, starting by recognizing the letters within a word, thus a sentence then a text.

- By making a combination of the language aspects, we can help the learner acquire a good pronunciation of sounds and words.

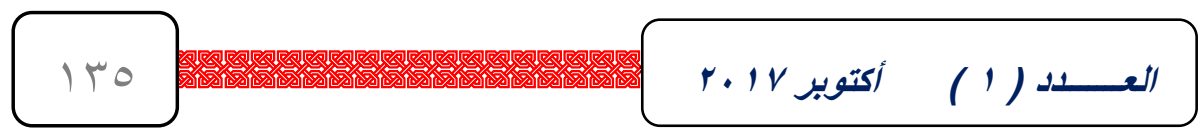






- Learners find it hard to distinguish between similar sounds, so it is advisable to practise these kinds of sounds.

First, pronounce in a separate form, the letters individually then collectively using long and short sounds as $\mathbf{t}(\overrightarrow{)})-\mathbf{t}(\boldsymbol{b})$ that create difficulty in both forms (heavy and light).

$$
\begin{aligned}
& \text { ( ta - tou - ti - ta: - tou: - ti: - ten - toun - ti:n ) } \\
& \text { (ta - tou - ți - ța: - tou: - ți: - țen - toun - ți:n ) }
\end{aligned}
$$

Then, learners are asked to pronounce the two sounds altogether in pairs. The aim is to reduce pronunciation difficulty.

$$
\begin{aligned}
& (\text { ta }- \text { ta })(\text { tou }- \text { tou })(\text { ti }- \text { t ti })(\text { ta: }- \text { ta: })(\text { tou: }- \text { tou: }) \\
& (\text { ti : - ți: })(\text { ten }- \text { ten })(\text { toun }- \text { toun })(\text { ti:n }- \text { ți:n })
\end{aligned}
$$

\begin{tabular}{|c|c|c|c|}
\hline \multicolumn{2}{|c|}{ Short sounds } & \multicolumn{2}{|c|}{ Long sounds } \\
\hline بنت bintoun (t) & نمط namatoun(t & ta:ba تاب & طب:ba ta: \\
\hline لفت lafata ( لف & سقط) sakața(t & tou:tounتوت & طوب:ou:boun \\
\hline
\end{tabular}

Next, pronounce it in words using short and long sounds.

Table 11: short and long sounds

After this, pronounce it within a word then a sentence. For instance, the teacher selects the heavy sounds which represent an obstacle for American learners like (h - gh - s - t $-\mathbf{d})$ ).

They are asked to pronounce them separately then within words, sentences and paragraphs. Here, we have to exploit the Communicative Approach to link between practice and the objective of learning the Arabic language.

If learning is for tourism, then the learner invests in sounds that

\begin{tabular}{|c|c|c|c|c|}
\hline h & gh & $\mathbf{S}$ & $t$ & d \\
\hline حبـافلةُة & غَبِ ghașa & صـــ șaydoun & 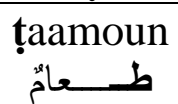 & ضــــبـبـُ \\
\hline דאו & & & $\mathrm{rel} \mathrm{Vs}$ & العـــــد ( ') \\
\hline
\end{tabular}
constitute a difficulty in situations where he wants to express his wishes and needs. The teacher will help him/her get over these obstacles. 


\section{الهالمة العربية لاناطقين بفيرها}

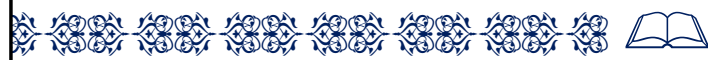

\begin{tabular}{|c|c|c|c|c|}
\hline 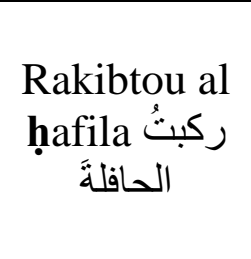 & $\begin{array}{l}\text { Aghțișou } \\
\text { filbaḥri } \\
\text { اغطُسُ فيحرِ البُرِ }\end{array}$ & $\begin{array}{c}\text { Aștadouss } \\
\text { amaka } \\
\text { أصطادُ السمكَ }\end{array}$ & $\begin{array}{l}\text { Atanawal } \\
\text { ouțțaama } \\
\text { أتناولُ الظعامَ }\end{array}$ & $\begin{array}{c}\text { Yaghloubouḍa } \\
\text { baboualaljaww } \\
\text { i } \\
\text { يغلبُ الضِّبُ على الجِّ }\end{array}$ \\
\hline
\end{tabular}

Table 12: An example of Communicative Approach

Finally, pronounce it inside a word, a sentence, and then build up a very short simple paragraph such as the following:

"Baadazawali al ḍabab, rakibtou al hafilawatawajjahtouilalbaḥri, liajli al ghaț̣iwașaydiașạamaki, wa fi mountașafinnaharijalaștouko rbachatiilitanawoulițtatami."

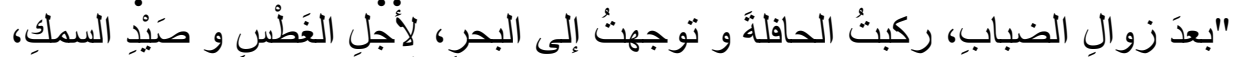

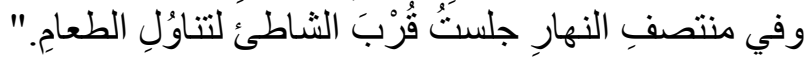

\section{Notes}

1-language syntaxmeans all that is related to sounds, conjugation, structure and lexis.

2_ WalidAl annati :"Applied Linguistics and Teaching Arabic to Non-natives"Eldjawhara (The Jewel)Publication and Distribution,Oman,Jordan ,2003, p.40.

3. Ahmed Hassani"Studies in Applied Linguistics"-domain of teaching languages- University press office, Ben Aknoun, Algiers, $2^{\text {nd }}$ edition, 2009, P. 131 .

4- same reference, p.134.

5- Ibrir Bashir Ibrahim "Teaching Texts: Theory and Practice" aalemelkoutubelhadith (The Modern World of Books) Publication and Distribution, Irbid, Jordan $1^{\text {st }}$ edition, 2007, p.3.

6- same reference, p.9-10.

7-WalidAnnati“"Applied Linguistics and Teaching Arabic to Nonnatives"Eldjawhara (The Jewel) Publication and Distribution,Oman,Jordan, 2003, p.36. 


\section{الهالة العربية للناطقين بغيرها}

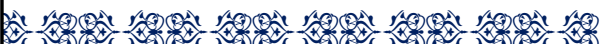

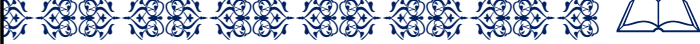

8- NaeefKhorma and Ali Hadjadj: "Foreign Languages - Teaching and Learning" - Aalem ElMaarifa (The World of Knowledge), National Council for Culture, Arts and Literature, Kuwait, ${ }^{\circ} 126$ July 1998, p.76.

* For Skinner, the acquisition of language for children is not only through stimulus and response but through trial and error: LaachbiAkila, University of Tiziouzou, Mother Language, essays from "Dar Houma" Magazine, 2009, p.99.

${ }^{9}$ - same reference, p.52.

${ }^{10}$ - Ibid , p.76.

${ }^{11}$-same reference, p.79.

${ }^{12-}$ NaeefKhorma and Ali Hadjadj: "Foreign Languages - Teaching and Learning "-AalemElMaarifa

( The World of Knowledge), National Council for Culture, Arts and Literature, Kuwait, n¹26 July 1998, p.76/

${ }^{13}$-WalidAnnati“Applied Linguistics and Teaching Arabic to Nonnatives"Eldjawhara( The Jewel) Publication and Distribution,Oman,Jordan ,2003, p.113.

${ }^{14}$-Abdou El Rajihi, "Applied Language Science and Arabic Teaching",DaarElMaarifaEldjamiaa (The House of University Knowledge), Alexandria, Egypt. Edition: 1995, p.46.

15 - Salah Belaid "Courses in Applied Linguistics" Dar Houma Publication and Distribution, Algiers, $6^{\text {th }}$ Edition, 2011, p.48.

16. Rochedi Ahmed Toeima"Cultural and Lexical Bases for Teaching Arabic to Non-native Speakers”, University of Um el Qura, Mecca, 1982, p.3-29.

17 - Ibid , p.40.

18 - NaeefKhorma and Ali Hadjadj: "Foreign Languages- Teaching and Learning" -AalemElMaarifa(The World of Knowledge),

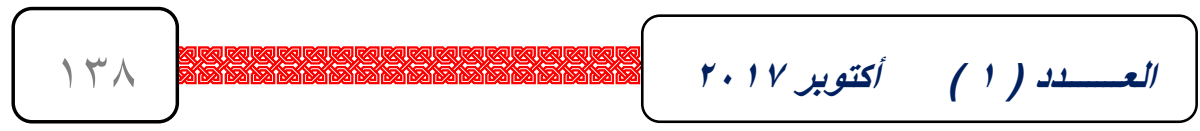




\section{المهلة العربية المناطقين بغيرها}

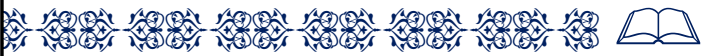

National Council for Culture, Arts and Literature, Kuwait, $\mathrm{n}^{\circ} 126$ July 1998, p.78

19-Badraoui Zahran"Contrastive Linguistics- A theoretical study" - Dar el Afak elArabia (Arabic Horizons House), Cairo, Egypt 1stedition , 2008 , p.40.

20-Mohammed Ali AbdelkarimErradini“"Linguistic and Literary Research Approach" Dar el Houda, AinM'lila, Alfgeria, 2010, p.204

21-Rochedi Ahmed Toeima "Linguistic Skills- levels, teaching, difficulties" - Dar El FikrElArabi ( Arabic Spirit House), Cairo, Egypt , 1st edition, 2004, p.10.

22-Mohammed Mohammed Daoud "Arabic and Modern Language Science" Dar El Gharib (The Stranger's House), Cairo, Egypt 2001, P.101.

23-Rochedi Ahmed Toeima "Linguistic Skills- levels, teaching, difficulties"-Dar El FikrElArabi ( Arabic Spirit House), Cairo, Egypt , 1st edition , 2004, p.10

24-Mahmoud Ismail El-SiniIshaak Mohammed El Amine "Language Concordanceand Error Analysis" Library Deans, King Saoud, Riadh University, 1st edition 1982 .

25-Rochedi Ahmed Toeima"Linguistic Skills- levels, teaching, difficulties"-Dar El FikrElArabi ( Arabic Spirit House), Cairo, Egypt , 1st edition , 2004, p.303 - 304.

26-Djasim Ali Djasim Magazine: "Studies for Human and Social Sciences"- Senior Scientific researcher, JordanUniversity Vol. 40 2nd issue, 2013, p.307.

27--Rochedi Ahmed Toeima“ Linguistic Skills- levels, teaching, difficulties"- Dar El FikrElArabi (Arabic Spirit House) , Cairo, Egypt, 1st edition, 2004, p.313.

28-Ibid, P. 318 \&334.






\section{الهمالة العربية لالناطقين بغيرها}



29--Rochedi Ahmed Toeima“" Linguistic Skills- levels, teaching, difficulties"- Dar El FikrElArabi (Arabic Spirit House), Cairo, Egypt , 1st edition , 2004, p.324.

30-same reference, P. 320.

31- SamirSherifIstitia: "Linguistics- Domain, Function and Approach" aalemelkoutubelhadith(The Modern World of Books), Irbid, Jordan, 1st edition , 2005 , p.469.

32- -Rochedi Ahmed Toeima" Linguistic Skills- levels, teaching, difficulties"-Dar El FikrElArabi ( Arabic Spirit House), Cairo, Egypt , 1st edition, 2004, p.318.

33-Ibid, P. 327.

34-same reference, p. 327.

35- Ibid, p. 327.

36- Ibid, p. $324-325$.

37- Mahmoud RamadhanEldiki "Number Construction in Arabic", ElManaara (The Lighthouse) Magazine University of El Bait. Jordan, Vol. 13, issue 4,2007, p.112.

38-Sayed Mohammed Redha\&SoumiaKadhmiNadjafAbadi: Study on the competency of dictionary for non-native speakers, Studies in Human Sciences' Magazine, Senior Scientific Researchers Jordan University, 1st issue, year 20,2013, p. 3.

39- BadraouiZahran "Contrastive linguistics- A theoretical study" Dar el AfakelArabia ( Arabic Horizons House), Cairo, Egypt 1stedition , 2008 , p.391.

40-Ibid, page 391.

41-BadraouiZahran "Contrastive Linguistics- A theoretical study" Dar el AfakelArabia ( Arabic Horizons House), Cairo, Egypt 1stedition, 2008 , p.391.

42-Yun Eun- Kyeong: " The Best Approach to Teach Arabic for Non-natives" - from the language social science's point of view- The

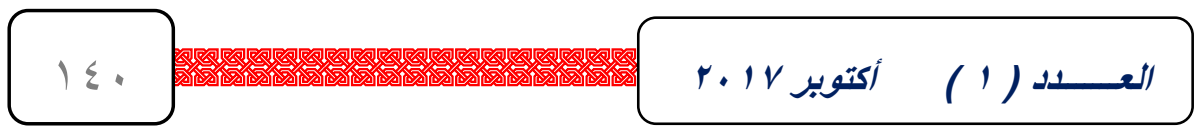




\section{الهابة العربية الاناطقين بفيرها}

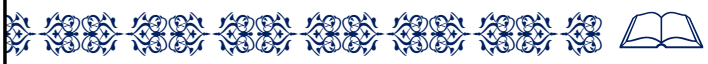

teacher's Magazine; university of Baghdad, Iraq issue 301 , 2013 , p.96.

43-DoucoureMassire\&SoumiaDafaa Allah Ahmed El Amine: "Phonological Problems for Non-native Learners of Arabic" El Madjmaa Magazine- The world's city University Malaysia, 2012 , p. 10 .

44-Abdou El Rajihi, "Applied Language Science and Arabic Teaching",Daar El MaarifaEldjamiaa(The House of University Knowledge), Alexandria, Egypt. Edition: 1995, p.124.

45-DoucoureMassire\&SoumiaDafaa Allah Ahmed El Amine: “ Phonological Problems for Non-native Learners of Arabic" El Madjmaa Magazine The world's city University Malaysia, 2012 , p.10.

\section{References:}

1-Abdou El Rajihi, "Applied Language Science and Arabic Teaching",DaarElMaarifaEldjamiaa (The House of University Knowledge), Alexandria, Egypt. Edition: 1995

2-Ahmed Hassani“Studies in Applied Linguistics" -domain of teaching languages- University press office, Ben Aknoun, Algiers, 2ndedition, 2009.

3-BadraouiZahran"Contrastive Linguistics- A theoretical study" Dar el AfakelArabia (Arabic Horizons House), Cairo, Egypt 1st edition , 2008.

4-Djasim Ali Djasim Magazine: "Studies for Human and Social Sciences"- Senior Scientific researcher, Jordan University Vol. 40; 2nd issue, 2013.

5-DoucoureMassire\&SoumiaDafaa Allah Ahmed El Amine: "Phonological Problems for Non-native Learners of Arabic" El Madjmaa Magazine- The world's city University Malaysia, 2012.

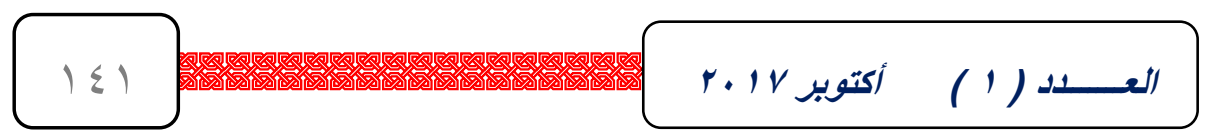




\section{المبلة العربية اللناطقين بغيرها}

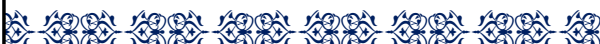
今

6-Ibrir Bashir Ibrahim "Teaching Texts: Theory and Practice" aalemelkoutubelhadith (The Modern World of Books ) Publication and Distribution, Irbid, Jordan 1st edition, 2007/

7- Kaddour Nabila: "Arabic \& French Linguistic Interference and its influence on the Learning of French in the Arabic Literature Department "-a Masters Degree memoir -Arts and Languages Department, Mantouri University, Constantine; 2015 -2006 8-LaachbiAkila: "The Mother Language" essays from Dar el Houma Magazine- university of Tizi-Ouzou, 2009.

9- Mohammed Ali AbdelkarimErradini"Linguistic and Literary Research Approach" Dar el Houda, AinM'lila, Alfgeria, 2010, 10-Mohammed Mohammed Daoud "Arabic and Modern Language Science” Dar El Gharib (The Stranger's House), Cairo, Egypt 2001 11-Mahmoud Ismail El-SiniIshaak Mohammed El Amine "Language Concordance and Error Analysis" Library Deans, King Saoud,Riadh University, 1st edition 1982.

12- Mahmoud Ramadhan Eldiki: "Number Construction in Arabic" El Manaara (The Lighthouse) Magazine University of El ElBait. Jordan, Vol. 13, issue 4, 2007.

13-Naeef Khorma and Ali Hadjadj: "Foreign LanguagesTeaching and Learning" -Aalem ElMaarifa (The World of Knowledge), National Council for Culture, Arts and Literature, Kuwait, $n^{\circ} 126$, July 1998.

14-Rochedi Ahmed Toeima“ Linguistic Skills- levels, teaching, difficulties"- Dar El FikrElArabi ( Arabic Spirit House) , Cairo, Egypt, 1st edition, 2004.

15-Salah Belaid "Courses in Applied Linguistics" Dar Houma Publication and Distribution, Algiers, 6thEdition, 2011.

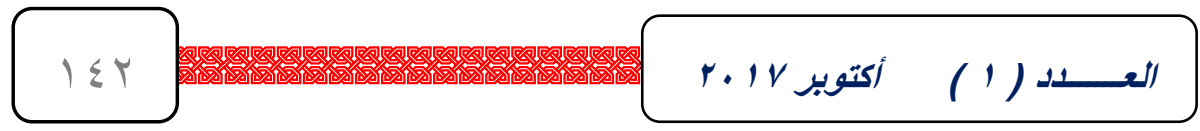


16-Samir SherifIstitia: "Linguistics- Domain, Function and Approach"aalem elkoutub elhadith (The Modern World of Books), Irbid, Jordan, 1stedition, 2005.

17- Sayed Mohammed Redha \& Soumia Kadhmi Nadjaf Abadi: 'Study on the competency of dictionary for non-native speakers, Studies in Human Sciences' Magazine, Senior Scientific Researchers Jordan University, 1st issue, year 20, 2013.

18-Walid Annati“"Applied Linguistics and Teaching Arabic to Non-natives" El djawhara (The Jewel) Publication and Distribution, Oman, Jordan, 2003/

19-Yun Eun- Kyeong: “ The Best Approach to Teach Arabic for Non-natives" - from the language social science's point of viewThe teacher's Magazine; university of Baghdad, Iraq issue 301 , 2013.

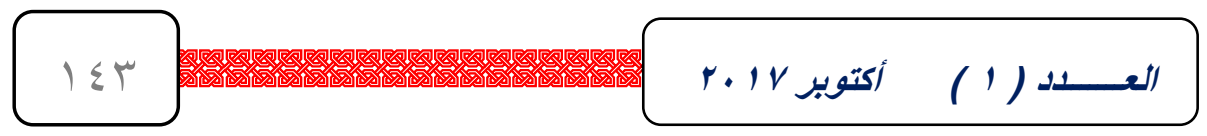

